\title{
CONFIRMATORY ANALYSIS OF FOOD SECURITY IN NORTH SUMATERA
}

\author{
Mohammad Yusri")1, Satria Tirtayasa*), Muhammad Said Siregar"), and R.S. Kartaatmaja ${ }^{* *}$ \\ *) Universitas Muhammadiyah Sumatera Utara \\ Jl. Kapten Muchtar Basri No.3, Glugur Darat II, Kota Medan, Sumatera Utara 20238 \\ ${ }^{* *}$ PT. Sembilan Pilar Bumi \\ Jl. TB Simatupang No 18 Jakarta Selatan, DKI Jakarta 12430
}

\begin{abstract}
This study aims to provide empirical evidence and investigations on the development of food security in North Sumatera Province (PSU). This research was conducted in districts/ cities in North Sumatera Province. Data collection techniques in this study were secondary data collection (aspects of food production per year in a cycle of two harvests calculated on an average, annual population growth rate and annual rice field area), observation and interviews. The analysis technique using Confirmatory Factor Analysis. The results showed that the trend of food security in the aspect of food production, in the aspect of production value, has generally decreased, so that the fulfillment of food production is only eighty percent and shortages each year are met through imports from other countries. Welfare in the PSU is determined by confirmatory factors with the availability of agricultural land, then population and food security.
\end{abstract}

Keywords: confirmatory analysis, food security, north sumatera, agriculture, starving

Abstrak: Penelitian ini bertujuan untuk memberikan bukti empiris dan investigasi terhadap perkembangan ketahanan pangan di Provinsi Sumatera Utara (PSU). Penelitian ini dilakukan di kabupaten / kota di Provinsi Sumatera Utara. Teknik pengumpulan data dalam penelitian ini adalah pengumpulan data sekunder (aspek produksi pangan pertahun dalam satu siklus dua kali panen yang dihitung rata-rata, laju pertumbuhan penduduk tahunan dan luas areal persawahan tahunan), observasi dan wawancara. Teknik analisis menggunakan Analisis Faktor Konfirmatori. Hasil penelitian menunjukkan bahwa trend ketahanan pangan dari aspek produksi pangan, pada aspek nilai produksi secara umum mengalami penurunan, sehingga pemenuhan produksi pangan hanya delapan puluh persen dan kekurangan setiap tahun dipenuhi melalui impor dari negara lain. Kesejahteraan di PSU ditentukan oleh faktor konfirmatori dengan ketersediaan lahan pertanian, kemudian jumlah penduduk dan ketahanan pangan.

Kata kunci: analisis konfirmatori, ketahanan pangan, sumatera utara, pertanian, kelaparan

\footnotetext{
${ }^{1}$ Corresponding author:

Email: mohd.yusri@umsu.ac.id
} 


\section{INTRODUCTION}

Food is the basic right of everyone. The 1948 universal human rights declaration of food is the basic right of every person: "... everyone has the right to a standard of living adequate for the health being of himself and his family, including for food ..." which is then refined by emphasizing the right to be free. From hunger: ".... the right of everyone .... to be free from hunger ....". Although FAO reported that in 2005 about 852 million people on the earth were suffering from hunger and malnutrition or energy adequacy figure, 12.6 million were Indonesian. Energy adequacy is a condition resulting from a lack of food consumption (Lenhart, 1998; Ngongi, 1999). The political decisions to eliminate poverty and the Energy adequacy figure from the earth Dara's face, the world leader. Rome Declaration at the World Food Summit in 1996 agreed: "... to eradicate hunger in all countries ... reducing numbers of undernourished people to half their present level no later than 2015 (FAO, 2002).

Five years after the Rome Declaration, in 2001, the FAO held another World Food Summit: five years later, to examine barriers to achieving goals and mobilize political commitment and financial support. WFS: five years later produced an International Alliance Against declaration that reaffirmed the commitment: (a) food security for everyone, (b) the right to every access to safe and nutritious food, and (c) international support in alleviating the main causes of hunger. The summit's target is that the number of earth's population suffering from hunger and malnutrition must be reduced by 24 million each year, or around 600 thousand for Indonesia, by 2015 (FAO, 2002). To achieve these targets, the Indonesian government, among others, has developed a concept of clear limits on the Energy adequacy figure, which will be used in planning, implementing, monitoring, and evaluating the Energy adequacy figure reduction program. Various Energy adequacy figure reduction programs have been implemented, both directly and indirectly, such as providing additional food for children, providing food assistance for malnourished children under five years of age, rice for the poor, providing assistance for victims of natural disasters, market operations basic needs, social safety net, direct cash assistance, assistance, development of independent food villages, empowerment of foodinsecure areas, and various credit schemes for small businesses, and medium.
Energy adequacy figure adversely affects public health: (a) high infant mortality, (b) susceptibility to disease: more than 2 million children die each year due to dehydration, diarrhea, (c) impaired growth and intelligence: an estimated 26 million children grow short ( stunted) from which is positively related to lower IQ, (d) public expenditure on health increases; and (e) stifling economic growth: nearly 67 million malnourished children due to chronic hunger are unable to finish school. This will lead to a lack of skills and productivity, which hinders economic growth (Oison, 1999; FAO, 2004). Rose (1999) noted several main causes of the Energy adequacy figure: increased real income prices, high unemployment, and limited food subsidies. Or suggest that poverty, government instability, environmental exploitation, the helplessness of children, women, and the elderly are generally the causes of hunger.

The Energy adequacy figure and poverty are like a circle: the Energy adequacy figure results in low productivity, low productivity results in low income, low-income results in low consumption, low consumption results in an Energy adequacy figure, an Energy adequacy figure results in low productivity and so on. And this circle does not end if there is no program available. The total population of North Sumatera Province (NSP) in 2015 was $13,937,797$ people. The population has continued to increase since 1990 . The average population growth rate for 2000 was $1.20 \%$ per year, the period 2009 2015 was $1.67 \%$ per year and was $1.82 \%$ per year.

The distribution of the NSP population is uneven. In 2015, the majority (9.83 million people; $70.5 \%$ in Medan, Sibolga, Tanjung Balai, Pematang Siantar, Tebing Tinggi, Padang Sidimpuan, Deli Serdang, Serdang Bedagai, Asahan, Langkat and Simalungun. Furthermore, 6.98 million people. (50.11\%) of the population live in rural areas, and the remaining 6.95 million people (49.89\%) in urban areas.

The NSP workforce in 2015 was 9,377,350 people, $8,472,436$ people $(90.35 \%)$ were classified as working, and 904,914 people $(9.65 \%)$ were classified as looking for work and not working (open unemployment). Most of the working labor force $(56.51 \%)$ work in the agricultural sector. The second-largest sector absorbing labor is trade, hotels, and restaurants with $18.08 \%$. Another sector whose role was quite large in absorbing labor was the services sector (individuals, companies, 
government), namely $8.02 \%$, while the industrial sector absorbed $17.39 \%$ of the workforce. Based on the work status of the NSP workforce who work, $25.30 \%$ are Laborers or employees; $18.35 \%$ family workers; $19.28 \%$ of employers who employ assisted family members; $4.09 \%$ employers who employ permanent/ non-family members.

The labor force participation rate, or called TPAK fluctuates. The TPAK in 2000 was $57.34 \%$, increased to $71.94 \%$ in 2005 , but fell to $66.90 \%$ in 2006 . In 2007 and 2008, the TPAK increased again to $67.49 \%$, $68.33 \%$, respectively, but fell again to $64.33 \%$ in 2009 and increased to $67.25 \%$ in 2015. Most of the workforce $(40.08 \%)$ have primary, or lower education, junior and senior high school education are $25.12 \%$ and $32.31 \%$, respectively, and the remaining $7.87 \%$ have above high school education.

The number of poor people in NSP has fluctuated. In 2004 the number of poor people was 80 million people (14.28\%), but the increase in fuel prices in March and October 2005 resulted in an increase in the number of poor people to 1.98 million people (15.66\%) in 2006 NSP's poor population continued to decrease since 2006, namely 1.77 million (13.90\%) in $2007,1.61$ million (12.55\%) in 2008, 1.50 million (11.51\%) in 2009 and 1.36 million (9.76\%) in 2014.

The data on the number of poor people above shows that even though it is decreasing, it still has a relatively high potential for Energy adequacy figure in the NSP and needs to be watched out for because it indicates food insecurity. This survey is intended to determine the spread and level of hunger and nutritional status of the NSP poor. The reason for the poor being the target of this survey is because they are a group of people who are vulnerable to Energy adequacy figures. The boundaries of the poor in this survey were households receiving direct cash assistance.

The solution approach to solving the problem in this research is with confirmatory analysis, on the factors that become the research indicators, it is obtained Food Production, Productivity Level, Production Distribution, Land Area, Agricultural Leasehold, Extensification, Land Distribution, Total of Population, Population Distribution and Growth Rate. as part of the guidelines for building analysis and taking a solution to get the optimal value and being a comparison of descriptive data for strategic decisions of all stakeholders.
The development of food security. And find the formulation to solve the problem of food security based on the availability of agricultural land and the explosion of population growth in North Sumatera Province. The research limitation is related to agriculture and agribusiness policy priorities.

\section{METHODS}

Field research will be carried out in several villages in North Sumatera Province. The research will be carried out from May 2017 until completing the research draft preparation in September 2017. This research was conducted with village and sub-district research units, with three villages from 23 districts and cities so that a total of 69 villages and wards in NSP. The research time cycle for one quarter is the basis for forming a time series for determining the optimal time for further research. The type of data in this study is primary data and comes directly from field observations in NSP.

Determination of research respondents using the method of taking research samples by means of purposive sampling as many as six respondents who meet certain criteria, namely: experienced, have the capacity and mastery of agricultural-related problems and understand social society. Respondent representation can be seen from the track record of involvement in food security in a village or sub-district. Taken with due observance of the track record related to food security. Respondents were taken from every village and sub-district in NSP.

From the results of observations and literature, this study finds indicators that are given a notation as a sign according to the numbering of each variable. Research indicator has a scale of interval and ratio measurement. And food security becomes an independent variable that is built through three dependent variables, namely food production, rice fields and population. A number of variables included in this study have operational definitions shown in Table 1.

In testing the proposed hypothesis, the data obtained will then be processed according to the needs of the analysis. For the purposes of discussion, the data is processed and presented based on the principles of descriptive statistics, while for the purposes of analysis and hypothesis testing, inferential statistics are used. To answer research questions and assess the model compiled, based on the flow characteristics and research 
data the analysis technique used is Confirmatory Analysis. This analysis is solving of hypothesis to provide solutions in data analysis results that have validity and reliability to research problems.

\section{Validity test}

A test or instrument can be said to have high validity if the tool performs its measuring function or provides measurement results that are in accordance with the purpose of the measurement. A valid measuring instrument is not only able to reveal data accurately and provide an accurate picture of the data. Accurate means that the measurement is able to provide an overview of the smallest difference between one subject and another. A valid measuring instrument is one that has a small error variance so that the resulting number can be trusted as a number that is close to the truth.

\section{Reliability Test}

This test is carried out to determine the internal consistency of the indicators of a construct that shows the degree to which each indicator identifies a common latent construct or factor. Or in other words how specific things help each other explain a general phenomenon. The approach used is to assess the composite reliability and variance construct extrated from each construct. With the following formula (Ferdinand, 2002):

Construct-reliability $=\sum$ StdLoading $2 /\left(\sum\right.$ Std Loading$\Sigma \in \mathrm{j})$
Where: Standard Loading obtained directly from the standardized loading for the indicator; $\mathrm{ej}$ (measurement error of each indicator).

The limit value used to assess an acceptable level of reliability is 0.70 , if the research being conducted is exploratory then a value below 0.70 is still acceptable as long as it is accompanied by empirical reasons that are evident in the exploration process.

In social science research, the research design is generally divided into three forms, there are explorative research, descriptive research and explanatory research (Umar, 1999). Exploratory research is a type of research that seeks to find new ideas or relationships. While descriptive research is research that aims to describe the characteristics or characteristics of a particular phenomenon. Quantitative methods are used to assess Food Security. Meanwhile, qualitative methods are used to obtain creative programs according to the interests and needs of local stakeholders. The framework of this research shown in Figure 1.

The research framework was built on the background of the NSP as an area that has experienced problems in food security over the last ten years. Based on observations and literature, it provides knowledge to build research hypotheses to obtain data using the respondent retrieval method in accordance with the research objectives because it has obtained a list of villages and subdistricts. Confirmatory analysis provides answers to data characteristics that produce indicators of a certain value as a basis for data visualization and provides inferential information in drawing conclusions.

Table 1. Definition, indicators and measurement of variables

\begin{tabular}{lcll}
\hline Variables & Notation & Indicators & Measurement Scale \\
\hline Food Production (Y1) & $\mathrm{Y}_{11}$ & Food Production & Interval \\
& $\mathrm{Y}_{12}$ & Productivity Level & Interval \\
& $\mathrm{Y}_{13}$ & Production Distribution & Interval \\
Rice Fields (Y2) & $\mathrm{Y}_{21}$ & Land Area & Interval \\
& $\mathrm{Y}_{22}$ & Agricultural Leasehold & Ratio \\
& $\mathrm{Y}_{23}$ & Extensification & Ratio \\
Population (Y3) & $\mathrm{Y}_{24}$ & Land Distribution & \\
& $\mathrm{Y}_{31}$ & Total of Population & Ratio \\
& $\mathrm{Y}_{32}$ & Population Distribution & Ratio \\
Food Security (Z) & $\mathrm{Y}_{33}$ & Growth Rate & Ratio \\
\hline
\end{tabular}




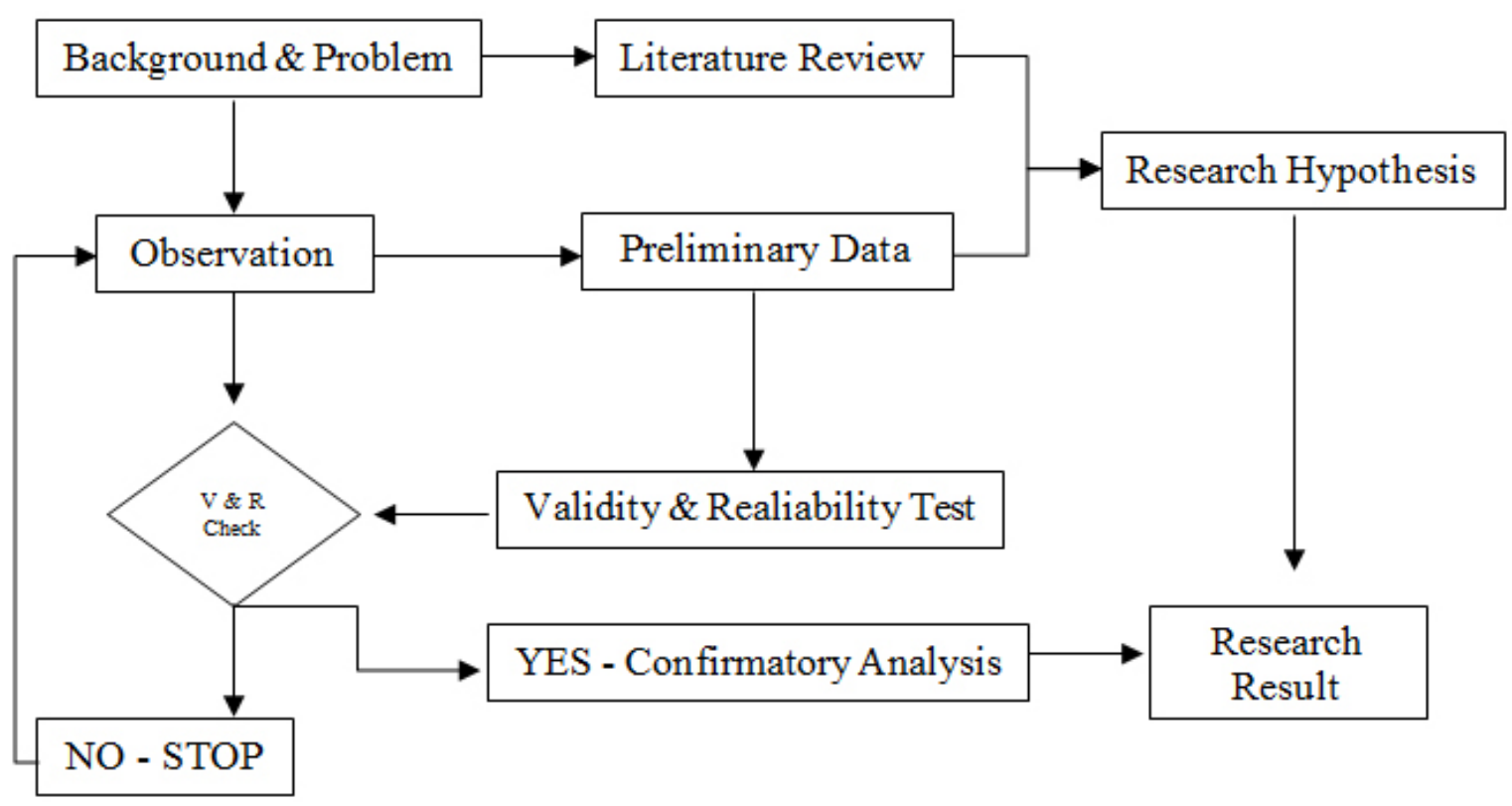

Figure 1. Research framework

\section{Research Hypothesis}

Based on the background of the problem, that the hypothesis is taken based on food security, which is correlated with social and economic indicators, the development of a region requires major building variables such as food security in relation to regional development in NSP. This research investigates the indicators of food production, rice fields, and population as the basis for the research objectives that have been formulated. The following research hypothesis is proposed:

1. The Food Security Program that is carried out affects the development based on the social-economic indicators.

2. Indicators of food production, rice fields, and population affect Food Security.

\section{RESULTS}

Starving or hunger is defined as a condition of yield and chronic lack of food consumption caused by the inability to get enough food (Lenhart, 1989; Ngongi, 1999). Meanwhile, by FAO (2003), hunger is defined as the inability to meet energy needs (on average throughout the year) to live a healthy, productive life and maintain a healthy weight. Starvation is also defined by Mason (2003) as food deprivation and undernourishment, or by Kennedy (2003) as feelings of restlessness or anxiety caused by lack of access to food.
Hunger is always directly related to a severe lack of food, which affects the sufferer's nutritional status; however, scientifically, there are two types of hunger: apparent hunger and hidden hunger. Hunger is defined as the inability of a person to meet food needs to live a healthy, smart, and productive life due to purchasing power and/or food availability. At the same time, less obvious hunger is associated more with a lack of consumption of micronutrients. Anthropometric measurements of apparent hunger can be seen, but subtle hunger is difficult to see with anthropometric measures but can be inferred through biochemical assessment of nutritional status or clinical examination. Remembering from the point of view of measuring apparent hunger is relatively easier to measure, then in the next discussion, what is meant by hunger is hunger unnoticeable.

In Indonesia, a definition of hunger has been developed, namely the condition of a person who is unable to meet food needs within a certain period because of the availability of food and the economy, in this case, people fasting, dieting, suffering from diseases are not included in this limit. Definition of hunger is developed with a time limit, so that is the inability of a person to meet the minimum food needs to live a healthy, smart, and productive life, for two consecutive months due to problems of purchasing power and/or availability of food and community values. Operationally hunger is the inability of a person to meet $70 \%$ or more of energy 
needs accompanied by weight loss due to purchasing power and/or food availability.

In the long term, chronic hunger will adversely affect public health and cause high public expenditure on health. Chronic hunger can cause:

a. High infant mortality rate,

b. Susceptibility to disease: more than 2 million children die each year from dehydration caused by diarrhea (Cook et al., 2004),

c. Impaired growth and intelligence: Chronic hunger causes children to lack the protein and micronutrients they need for optimal growth. It is estimated that 26 million children in the world are growing shorter (stunted) than they should. Consequently, stunted children are positively associated with lower IQ (Oison, 1999), and

d. Stunts economic growth: nearly 67 million children are malnourished due to chronic smoking and cannot complete school well. This will lead to a lack of skills and productivity, which hinders a country's economic growth (FAO, 2004).

Hunger is contrary to the 1948 universal human rights declaration on the right to food which states: "... everyone has the right to a standard of living adequate for the health and well-being of himself and his family, including for food ...." The Human Rights Declaration on the right to food is then refined by emphasizing the right to be free from hunger: "... the right of everyone to ... adequate food and speifying the fundamental right of everyone to be free from hunger ...".

Poverty, instability of government systems, use of the environment that exceeds capacity, discrimination, and powerlessness such as children, women, and the elderly are the causes of world hunger (FAO, 2003). Likewise, limited food subsidies, increasing food prices, decreasing real income, and high unemployment are the main factors causing hunger (Rose, 1999). Hunger and poverty are like a circle: hunger results in low productivity $->$ low-income $->$ low consumption -> low productivity. This cycle does not end if there are no prevention programs available.

Nutritional status is defined as the state of health of a person or group of people due to the consumption, absorption and use of nutrients. Foods that meet the nutritional needs of the body will lead to a good nutritional status. Nutritional status can describe the state of one's consumption and health. The assessment is approached by assessing the nutritional status of children under five. In this matter, the nutritional status of children under five is an indicator of community nutrition's health condition in certain areas because children under five are sensitive to changes in nutritional conditions in society (Sediaoetama, 1993). The assessment method is the prevalence of certain nutritional status of children under five, namely by calculating the percentage of children with a specific nutritional status (malnutrition or malnutrition) to the total number of children being measured (Suhardjo and Riyadi, 1990). The nutritional status of a person or group of people can be determined by measuring their nutritional status, including measurement of food consumption (indirect measurement), anthropometry, and clinical (direct measurement). The method and indicators used will depend on the stage of malnutrition, time, cost, the accuracy of the desired assessment, and the number of people whose nutritional status will be assessed.

The anthropometric method is a method that is widely used because it is relatively simple. According to Jellife in Gibson (1990), anthropometrics is a measurement of variations in the physical dimensions and gross composition of the human body at different age and nutritional levels. Several kinds of indicators that can be used include weight, height, upper arm circumference, LILA, and age. The anthropometric measurement index used in the assessment of nutritional status differs based on age and sexual maturity as follows: For children up to 12 years of age: weight index for age (W/A) is used, height index for age, weight index for height, and index for upper arm circumference according to age. For adolescents aged 13-19 years: body mass index (body mass index) according to age is used. For adults aged 20 years and over: anthropometric measurements are used body mass index.

Bodyweight for age provides an overview of body mass (muscle and fat). Body mass is very sensitive to sudden changes. Therefore the W/A indicator is more representative of the current nutritional status (current nutritional status). The advantages of this indicator are: It can be understood easily; It is sensitive to assess changes in nutritional status in the short term; It can detect being overweight.

The drawbacks are (a) it can lead to misinterpretation of nutritional status if there is edema, (b) requires accurate age data, especially for the under-five age group, (c) 
measurement errors such as clothes not being removed or the child constantly moving when weighed, (d) local socio-cultural problems do not want to weigh children because they are considered merchandise (Gibson, 1990; Riyadi, 1995, Soekirman, 1999).

Height for age (height / age) describes the state of sekeletal growth. In contrast to body weight, height is less sensitive to short-term nutritional deficiencies. Therefore the H/A index is more representative of past nutritional status. This indicator is closely related to the problem of the economy. Therefore, apart from being an indicator of nutritional status, it can also be used as a social, economic development measure for the community. The advantages of the H/A indicator are (a) it provides a past nutritional status, (b) it can be used as an indicator of socio-economic development. The weaknesses are (a) difficulty in measuring the height of children under five, (b) lack of nutrition at present, (c) requires accurate age data that is difficult to obtain to develop (Gibson, 1990; Riyadi, 1995, Soekirman, 1999).

Bodyweight has a positive linear relationship with height. The $\mathrm{H} / \mathrm{W}$ indicator is the best in anthropometric measurements. This indicator describes a specific and sensitive area's current nutritional status and is usually used when accurate age data is difficult to obtain. index weight/height is (a) independent of age, (b) can assess wasting status, and $\mathrm{r} \mathrm{Fc}$ ) marasmus condition or other severe KEP. The weaknesses are (a) when $\mathrm{i}$ :> tightness of the body because it is not corrected with clothes and the child moves constantly, (b) difficulty $n$ the height of the toddler, (c) does not give a picture of whether the child is short, (Gibson, 1990; Riyadi, 1995, Soekirman, 1999). The nutritional status is based on the index weight/age, height/age, and weight/height observed in standardized. There are two assessment methods, namely percent of the median (Table 2 ) and z score (Table 3). -use $\mathrm{z}$ score is the calculation result that has been standardized according to standard deviation so that $\mathrm{n}$ for each age group and the anthropometric index. The determination of the prevalence with the $\mathrm{z}$ score is more accurate than the percent method.

Body mass index, or BMI, is a careful indicator to determine deposits in body fat in a population (Forbes, 1988; Berkey et al., 2002). Based on the measurement results, the magnitude of nutritional problems that occur in adolescents and adults is known. Assessment of adolescent nutritional status is based on BMI/A based on the percentile value of weight and TB as recommended by WHO. A teenager is classified as thin if BMI/A $<5$ th percentile, classified as normal if BMI/ $\mathrm{U}$ is between 5 th percentile to 85 th percentile, and classified as obese or at risk of obesity if BMI/A $>85$ th percentile. The nutritional status of adolescents based on BMI/A values shown in Table 4.

Table 2. Nutritional status criteria for children according to weight / age, height / age and weight / height based on the percent calculation of the median

\begin{tabular}{lcll}
\hline Variables & Notation & Indicators & Measurement Scale \\
\hline Food Production (Y1) & $\mathrm{Y}_{11}$ & Food Production & Interval \\
& $\mathrm{Y}_{12}$ & Productivity Level & Interval \\
& $\mathrm{Y}_{13}$ & Production Distribution & Interval \\
Rice Fields (Y2) & $\mathrm{Y}_{21}$ & Land Area & Interval \\
& $\mathrm{Y}_{22}$ & Agricultural Leasehold & Ratio \\
& $\mathrm{Y}_{23}$ & Extensification & Ratio \\
Population (Y3) & $\mathrm{Y}_{24}$ & Land Distribution & \\
& $\mathrm{Y}_{31}$ & Total of Population & Ratio \\
& $\mathrm{Y}_{32}$ & Population Distribution & Ratio \\
Food Security (Z) & $\mathrm{Y}_{33}$ & Growth Rate & Ratio \\
\hline
\end{tabular}


Determination of the limit of normal body weight in adults based on the value of BMI is calculated by the formula weight $(\mathrm{kg})$ divided by the square of height $(\mathrm{m})$ : $\mathrm{BMI}=\mathrm{BW} / \mathrm{TB} 2$. The limit of normal BMI values for women is 18.7 - 23.8 or around 20.8 (Atmarita, 1992). Becker et al. (1999) stated that if a BMI of less than 20 is classified as underweight, 20-25 are classified as normal, 25-30 are classified as overweight, and more than 30 are classified as obese. The Ministry of Health categorizes adults' five nutritional statuses based on BMI values as in Table 5.

\section{Nutritional Status of Poor Household Members}

The distribution of poor household members in districts/ cities and North Sumatera in 2016 according to their nutritional status in Table 6 . In this case the nutritional status is classified into four, namely the combination of poor nutritional status in children, and very thin in adults), thin (a combination of underweight nutritional status in children, underweight in adolescents, and underweight in adults), normal (combined normal nutritional status in children, normal in adolescents, and normal in adults), and more (combined nutritional status in children, overweight in adolescents, overweight and obese in adults). The survey results show that malnutrition is not yet a problem for poor households in North Sumatera in 2016 because the prevalence is four point three percent, is smaller and the cut-off point for malnutrition is similar to all districts / cities, except Nias and Serdang Bedagai. Poor malnutrition is not a problem in other districts / cities, because the prevalence of malnutrition is less than five percent.

Table 3. Criteria for the nutritional status of children by weight/age, height/age and weight/height based on z score calculation

\begin{tabular}{lll}
\hline Index & Z score value & Nutritional Status \\
\hline & $\mathrm{z}<-3 \mathrm{SD}$ & Poor (underweight) \\
W/A & $-3 \mathrm{SD} \leq \mathrm{z}<-2 \mathrm{SD}$ & Less (underweight) \\
& $-2 \mathrm{SD} \leq \mathrm{z} \leq 2 \mathrm{SD}$ & Normal \\
& $\mathrm{z}>2 \mathrm{SD}$ & Very Good \\
& $\mathrm{z}<-3 \mathrm{SD}$ & Stunting \\
$\mathrm{H} / \mathrm{A}$ & $-3 \mathrm{SD} \leq \mathrm{z}<-2 \mathrm{SD}$ & Stunting \\
& $-2 \mathrm{SD} \leq \mathrm{z} \leq 2 \mathrm{SD}$ & Normal \\
& $\mathrm{z}>2 \mathrm{SD}$ & Very Good \\
& $\mathrm{z}<-3 \mathrm{SD}$ & Wasting \\
W/H & $-3 \mathrm{SD} \leq \mathrm{z}<-2 \mathrm{SD}$ & Wasting \\
& $-2 \leq ; \mathrm{SD} z \leq 2$ & Normal \\
& $\mathrm{z}>2 \mathrm{SD}$ & Very Good \\
\hline
\end{tabular}

Table 4. Adolescent Nutritional Status Criteria Based on BMI Value by Age

\begin{tabular}{ll}
\hline Nutritional Status & \multicolumn{1}{c}{ BMI Value } \\
\hline Thin & BMI $<$ fifth percentile \\
Normal & BMI between fifth to eighty fifth \\
& percentile \\
Fat Risk & BMI $>$ eighty fifth percentile \\
\hline
\end{tabular}

Table 5. Criteria for Adult Nutritional Status Based on BMI Value

\begin{tabular}{lc}
\hline Nutritional Status & BMI Value \\
\hline Skinny & $<17.0$ \\
Thin & $17.0-18.4$ \\
Normal & $18.5-25.0$ \\
Fat & $25.1-27.0$ \\
Fat Risk & $>27.0$ \\
\hline
\end{tabular}


Table 6. Distribution of poor household members according to nutritional status

\begin{tabular}{lcccc}
\hline \multirow{2}{*}{\multicolumn{1}{c}{ District/Cities }} & \multicolumn{3}{c}{ Distribution of poor households based on nutritional status (\%) } \\
\cline { 2 - 5 } & Poor & Less & Normal & Good \\
\hline Asahan & 0.0 & 0.0 & 100.0 & 0.0 \\
Dairi & 0.0 & 3.7 & 96.3 & 0.0 \\
Deli Serdang & 0.0 & 7.1 & 92.9 & 0.0 \\
Humbang Hasundutan & 0.0 & 2.2 & 97.8 & 0.0 \\
Langkat & 1.1 & 3.4 & 95.5 & 0.0 \\
Nias & 2.1 & 3.2 & 94.7 & 0.0 \\
Nias Barat & 0.0 & 1.9 & 98.1 & 0.0 \\
Nias Utara & 1.4 & 0.0 & 98.6 & 0.0 \\
Pakpak Bharat & 0.0 & 7.7 & 92.3 & 0.0 \\
Serdang Bedagai & 2.5 & 0.0 & 95.0 & 2.5 \\
Simalungun & 0.0 & 0.0 & 100.0 & 0.0 \\
Tanjung Balai & 0.0 & 0.0 & 100.0 & 0.0 \\
Labuhan Batu & 100.0 & 0.0 & 0.0 & 0.0 \\
Labuhan Batu Selatan & 100.0 & 0.0 & 0.0 & 0.0 \\
Padang Sidempuan & 100.0 & 0.0 & 0.0 & 0.0 \\
Tebing Tinggi & 100.0 & 0.0 & 0.0 & 0.0 \\
Tapanuli Tengah & 93.3 & 6.7 & 0.0 & 0.0 \\
Labuhanbatu Utara & 100.0 & 0.0 & 0.0 & 0.0 \\
Binjai & 100.0 & 0.0 & 0.0 & 0.0 \\
Karo & 100.0 & 0.0 & 0.0 & 0.0 \\
Padanglawas Utara & 100.0 & 0.0 & 0.0 & 0.0 \\
Tapanuli Utara & 100.0 & 0.0 & 0.0 & 0.0 \\
Toba Samosir & 0.0 & 0.0 & 100.0 & 0.0 \\
Sumatera Utara & 14.9 & 2.2 & 82.8 & 0.1 \\
\hline
\end{tabular}

Validity and Reliability Test

Test the validity or level of accuracy, accuracy or accuracy or the ability of indicators to measure what is related to food security in NSP. The research reliability test tests the index that shows the extent to which the indicators in Table 7 can be trusted or relied upon as a research reference. Both of these tests were conducted with the aim of reducing bias in the study. Based on the arrangement of variables and indicators, it is described in Table 7 related to validity and reliability test.

\section{Confirmatory Factor Analysis}

The model identification based on the degree of freedom obtained a model with $\mathrm{df}=54$ which shows the model is over-identifed, the estimation results allow the model to be rejected, a model with this condition is the desired model in the analysis. From Figure 2, it can be explained that the direct effects of exogenous latent variables on endogenous latent variables can be explained. Whereas the Food Security $(\mathrm{Z})$ variable is formed by two aspects, where the contribution of the Food Security Aspect $(Z)$ is 0.548 per time unit, while the Food Production variable (Y1) contributes 0.799 to the Food Security (Z) and the Rice Field variable (Y2) contributed 1.02 and Population (Y3) was 0.9 to Food Security (Z). Thus the direct effect does not provide significant results with positive standardized estimates and trend series values.

Law No.7 of 1996 on Food defines food security as a condition for the fulfillment of food for every household, which is reflected in the availability of sufficient food, both in quantity and quality, safe, equitable and affordable. The definition of food security includes macro aspects, namely the availability of sufficient food; and at the same time the micro aspect, namely the fulfillment of the food needs of each household to lead a healthy and active life. At the national level, food security is defined as the ability of a nation to ensure that all its inhabitants receive sufficient food, of appropriate quality, and safety; and based on optimal use and based on the diversity of local resources. 
Table 7. Validity and reliability test

\begin{tabular}{lclccc}
\hline Variables & Not. & \multicolumn{1}{c}{ Indicators } & R-Value & Critical Point & Note \\
\hline Food Production (Y1) & & & & & \\
& Y11 & Food Production & 0,784 & 0,374 & Valid \& Reliabel \\
& Y12 & Productivity Level & 0,719 & 0,374 & Valid \& Reliabel \\
& Y13 & Production Distribution & 0,766 & 0,374 & Valid \& Reliabel \\
Rice Fields (Y2) & & & & & Valid \& Reliabel \\
& Y21 & Land Area & 0,552 & 0,374 & Valid \& Reliabel \\
& Y22 & Agricultural Leasehold & 0,649 & 0,374 & Valid \& Reliabel \\
& Y23 & Extensification & 0,713 & 0,374 & Valid \& Reliabel \\
Population (Y3) & Y24 & Land Distribution & 0,746 & 0,374 & Valid \& Reliabel \\
& & & & & Valid \& Reliabel \\
& Y31 & Total of Population & 0,829 & 0,374 & Valid \& Reliabel \\
\hline
\end{tabular}

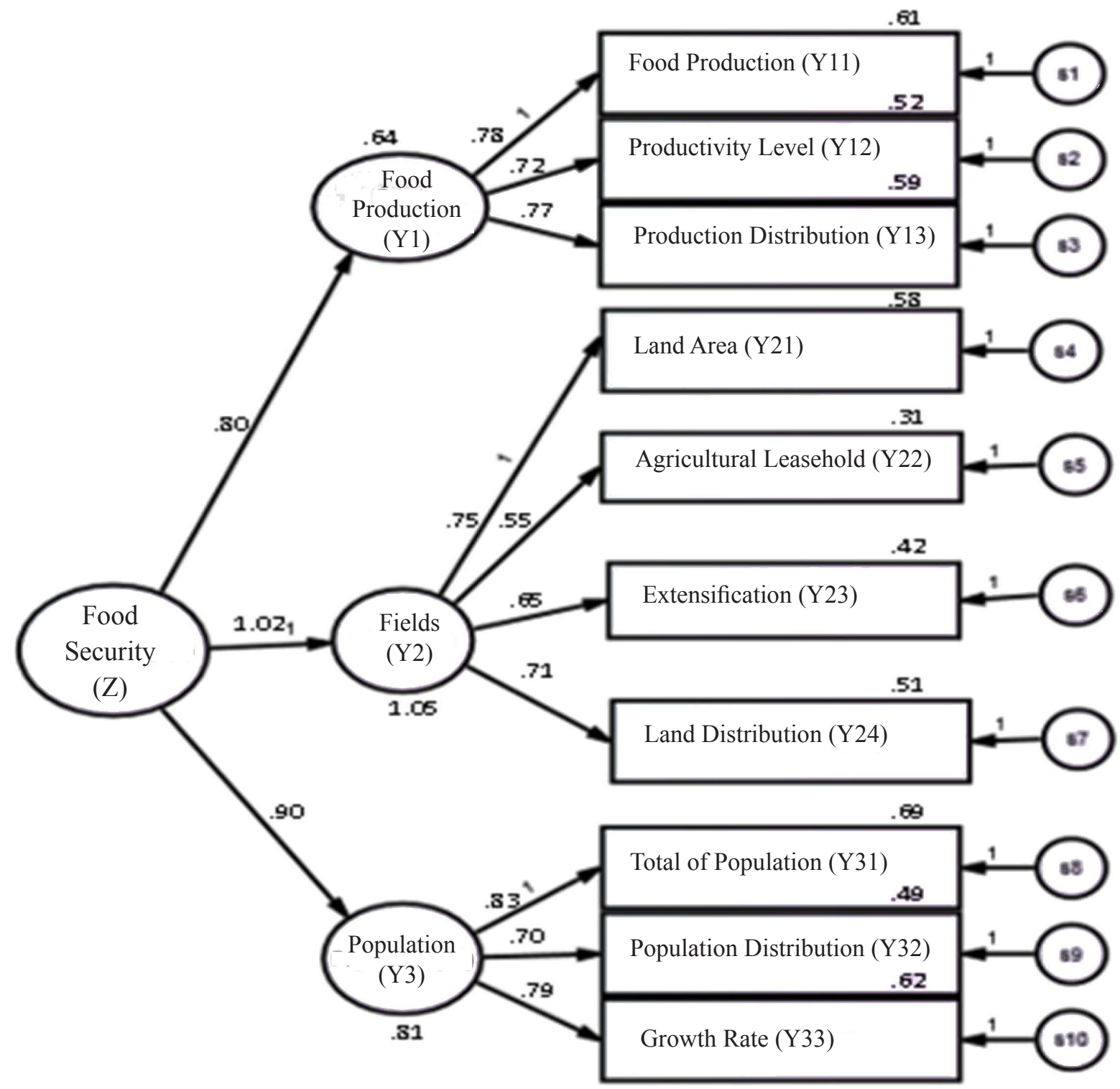

Figure 2. Path analysis of food security in North Sumatera 
Food security is a system consisting of the subsystem of availability, distribution and consumption. The food availability subsystem functions to ensure the supply of food to meet the needs of the entire population, both in terms of quantity, quality, diversity and safety. The distribution subsystem functions to create an effective and efficient distribution system to ensure that all households can obtain food in sufficient quantity and quality at all times at affordable prices. Meanwhile, the consumption subsystem has the function of directing the national pattern of food utilization to comply with the principles of quality, diversity, nutritional content, safety and halalness. The food security situation in our country is still weak. This is indicated by, among others: (a) the number of people who are food insecure (consumption level $<90 \%$ of the recommended 2,000 $\mathrm{kcal} / \mathrm{cap} /$ day) and very food insecure (consumption level $<70 \%$ of the recommendation) is still quite large, namely 36.85 million and 15.48 million people for 2002; (b) undernourished children under five are still quite large, namely 5.02 million and 5.12 million in 2002 and 2003 (Ali Khomsan, 2003).

By looking at the results of the analysis of food security trends in the aspect of food production, so far the value of production has always decreased in general, so that the fulfillment of food production is only $80 \%$ and leaves an average shortage of $20 \%$ per year which must be met by importing from other countries. This is when viewed from the existing parameters, it turns out that from the side of agricultural production alone it still does not meet national food needs, plus a productivity level of $72 \%$ which is expected to be $100 \%$ even with the vertical farming concept it is expected to reach the optimal number, namely $100 \%$, then the wetland aspect which has a significant reduction value, the depreciation of the national rice land harvest area in 2010 shrank by 12.63 thousand hectares or $0.1 \%$ of the total land area. Overall, agricultural land in Indonesia is decreasing by 27 thousand hectares per year. Thus, the decline in harvested area did not only occur for rice, but also for other commodities, such as soybeans. Reduced rice fields can be due to their function being converted to non-agricultural land (conversion of function) or into non-rice agricultural land (crop conversion). The phenomenon of conversion of paddy fields has been around for a long time, but the government's response is still more of a discourse. The reduction in paddy fields is mostly due to crop conversion, namely that the paddy fields are not currently planted with rice but instead planted with other types of crops, both seasonal and annual crops. This implies that lowland rice farming is no longer attractive to rural farmers, this is a problem that must be resolved in the near term, the concept of vertical farming becomes a concept of developing agricultural innovation that will create land efficiency and optimal productivity with contribution value. against food security which will increase by around $54.8 \%$.

Based on the definition of food security from FAO (1996) and RI Law no. 7 of 1996, which adopted the definition from FAO, there are 4 components that must be met to achieve food security conditions, namely: Adequacy of food availability; Stability of food availability without fluctuation from year to year; Accessibility / affordability to food as well; Food quality / safety.

According to Bustanul Arifin (2005) food security is a challenge that gets priority to achieve national welfare in this millennium. If you look at the explanation of PP 68/2002, efforts to achieve national food security must rely on local food resources that contain diversity between regions. Since 1798 when Thomas Malthus warned that the number of people is increasing exponentially, while the effort to increase the food supply can only increase arithmetic. In the course of history, various incidents of local famine can be recorded which have sometimes expanded to become very severe national famines in various countries. The problems above are the characteristics of a country that is not yet independent in terms of food security (Nasoetion, 2008).

Food security is a pillar for the development of other sectors. This is considered strategic because no country is able to build an economy without first solving its food problem. In Indonesia, the food sector is a determining sector for the level of welfare because most of the population who work on-farm for those in rural areas and for urban areas, there are still many people who spend their income for consumption. With this in mind, food self-sufficiency is an absolute prerequisite for national security. One of the strategic steps to maintain national resilience is through efforts to achieve food selfsufficiency. Conceptually, independence is a condition where there is no dependence on anyone and no one party can dictate or rule in matters relating to food. In the analysis of food security trends, the researchers found that with an exponential population growth rate of $1.1 \%$ each year with a correlation with a decrease in paddy fields of $0.1 \%$ and seeing an average deficit 
of $20 \%$ national food availability, it was obtained by analyzing the trend series in the year. 20 or around 2037 with a constant rate, Indonesia will have an emergency food security or a food crisis for the majority of the population. This will also trigger adequate nutritional figures and adequate energy figures, where the average energy sufficiency is the average energy requirement per capita per day, amounting to 2,000 calories according to WNPG VIII 2004.

Food self-sufficiency cannot be realized without the role of the government and society. Farmers who are at the forefront of local food supply, must receive attention and support from the government. The heart of food self-sufficiency lies in the quality and productivity of agriculture so the government must take sides and fully support the farmers. In addition, price policies can also support the stabilization and realization of food selfsufficiency. A more precise policy in the context of realizing food self-sufficiency is to change the habits of urban communities with the concept of urban vertical farming which is carried out in big cities in Indonesia.

Food security does not only include the definition of adequate food availability, but also the ability to access (including purchase) food and the absence of food dependence on any party. In this case, farmers have a strategic position in food security: farmers are food producers and farmers are also the largest consumer group, some of whom are still poor and need sufficient purchasing power to buy food. Farmers must have the ability to produce food and must also have sufficient income to meet their own food needs. This is where the role of the government is very necessary in empowering urban farmers who will become the new mainstream to make agricultural land vertically in urban areas. Because from the current farmer aspect, the researchers found that the relatively low and declining welfare of food farmers today will greatly determine the prospects for national food security. This welfare is determined by various factors and limitations, including:

a. Some farmers are poor because they do not have any productive factors except their labor (they are poor because they are poor), in this case the limited human resources available (the low quality of education that farmers generally have) is a quite complicated problem, on the other hand Structural poverty has made farmers' access to education very minimal.

b. Farmers' land area is narrow and is under pressure to continue to convert. In general, farmers in Indonesia on average only own less than $1 / 3$ hectare of land, from the production point of view, of course this type of land cannot be used to fulfill daily life for farmers.

c. Limited access to financial support services, the availability of capital needs more attention by the government. In general, the most fundamental problem experienced by farmers is limited capital, both in the provision of fertilizers or seeds.

d. The absence or limited access to better information and technology. Most of the farmers in Indonesia still cultivate the land in the traditional way, only a small proportion of them already use sophisticated technology. Of course, the production is very limited and cannot be maximized.

e. Inadequate production infrastructure (water, electricity, roads, telecommunications). The majority of agriculture in Indonesia is still in rural areas so that access to supporting facilities and infrastructure such as water, electricity, good road conditions and telecommunications is very limited.

f. The market structure is unfair and exploitative due to the very weak bargaining position of the farmers.

g. The inability, weakness or ignorance of the peasants themselves.

Without a basic and comprehensive solution in various aspects above, the welfare of farmers will be threatened and food security will be very difficult to achieve. So this is where the role of community empowerment by the government must be the main concern for the realization of food security because food security can be realized properly if the management is managed starting from the micro level (starting from the household), if people's access to food needs is good then food security in macro level will automatically be realized.

\section{Managerial Implications}

Managerial implications of research make a method of food security with a confirmatory analysis formula as a comparison for every policy for stakeholders in determinate priority of production value, agricultural land and population growth rate. In implementing efforts to improve food security, this approach can be a solution for regions to have safety networks, especially during the COVID-19 pandemic. The government's policy priorities have a significant effect in maintaining distribution channels and access to the community, especially in determining the price and availability of agricultural land. 


\section{CONCLUSIONS AND RECOMMENDATIONS}

\section{Conclusions}

The conclusion that can be drawn from this research is that food security is closely related to national security, economic stability, especially from food production, agricultural land and population. In Indonesia, the food sector is a determinant of the level of welfare because most of the population still works on-farm and some residents still spend their income for consumption. So that one solution to the limited agricultural land and population growth rate, namely Urban Vertical Farming, produces economic valuations that help the economy of urban and suburban communities. In food security, people are given knowledge and guidance to be aware of nutritional fulfillment. Strengthening food security is carried out by increasing the availability of food at the household level by developing local commodities, increasing agricultural productivity through accelerated use of technology in accordance with the capacity of local human resources, intensive and sustainable guidance and assistance in community empowerment programs, strengthening networks and commitment of all stakeholders. towards efforts to improve community welfare through increasing household-based food security.

\section{Recommendations}

Recommendations for managerial implications of research make a method of food security with a confirmatory analysis formula as a comparison for every policy for stakeholders in determinate priority of production value, agricultural land and population growth rate. In implementing efforts to improve food security, this approach can be a solution for regions to have safety networks, especially during the COVID19 pandemic. The government's policy priorities have a significant effect in maintaining distribution channels and access to the community, especially in determining the price and availability of agricultural land.

\section{REFERENCES}

Adekoya E, Adegbenga. 2015. Food insecurity and coping strategies among rural households in Oyo State, Nigeria. Journal of Food, Agriculture, and Environment 7: 187-191.

Agustina AS. 2015. Analysis of household food
Security based on proportion of food expenditure and energy consumption. Agrisep Journal 16(1): 20-34.

Ali MSS, Majika A, Salman D, 2017. Foodcosumption and production of Tempelake, South Sulawesi, Indonesia. Journal of Asian Rural Studies 1(1): 43-52. https://doi.org/10.20956/jars.v1i1.723.

Arifin B. 2004. Indonesian Agricultural Economic Analysis. Jakarta: Kompas Book Publisher.

Baliwaty YF. 2004. Introduction to Food and Nutrition, Printing I, Jakarta: Swadaya.

[FAO / WHO]. 1992. Paper Presented at International Conference or Nutrition Goals: World Declaration and Plan of Action. Rome / Geneva: FAO / WHO.

Ilham, Nyak, Bonar MS. 2015. Use of share of food expenditure as a composite indicator of food security. SOCA, Journal of Socio-Economic Agriculture and Agribusiness 7(3): 213-328

Janti GI, Martono E, Subejo. 2016. Protection of sustainable food agricultural land to strengthen regional food security (study in Bantul Regency, Yogyakarta Special Region). Naional Resilience 22 (1): 1-21.

Jaya PHI. 2018. Fate of farmers and regional food security (study of government policy and community response of Mulyodadi village, bantul when prices of agricultural commodities rise). Naional Resilience 24 (1): 77-79. https:// doi.org/10.22146/jkn.32923.

Kamaluddin A, Ala MSS, Ali DS, 2012. The adaptation of rice paddy farmers towards climate change. American-Eurasian of Agricultural \& Environmental Sciences 12(7): 967-972.

Kifli WF, Mulyo HJ, Darwanto DH. 2017. Theinfluence of social capital on farmers' household food demand in Riau Province. Journal of Management and Business 14(3):273.

Kurniasih M. 2015. Implementation of the urban farming program as a strategy for urban food security development (study in Made Village, Sambikerep District, Surabaya City). Journal of Public Administration 3(3): 52-72.

Mulyo HJ, Sugiyarto, Widada WA. 2015. food resilience and independence of marginal farmers' households in Bojonegoro Regency. Journal of Agro Economics 26(2):121-128. https://doi. org/10.22146/agroekonomi.17265.

Niko N. 2019. Poverty of Dayak Benawan women in West Kalimantan as a new form of colonialism. Journal of Sociological Thought 6 (1): 58-76. 
https://doi.org/10.22146/jps.v6i1.47467.

Niko N, Samkamaria. 2019. International Freight Terminal (TBI) in the context of community economic development at the entikong border, Indonesia-Malaysia. Indonesian Journal of Religion and Society 1(2): 104-114.

Pujiati S, Pertiwi A, Silfia CC. 2020. Analysis of food availability, affordability and utilization in supporting the achievement of community food security in Central Java Province. Sodial Journal of Agricultural Economics 16(2).

Purwaningsih Y, Sutomo, Istiqomah N. 2015. Analysis of the impact of land function transfer on the level of farm household food security in Karanganyar 1(2).https://doi.org/10.18196/agr.1213.
Putri ZR. 2015. Analysis of the causes of the change in the function of agricultural land to nonagricultural land in Regencies/Cities in Central Java Province 2003-2013. Eco-Regional 10(1): $17-22$

Riajaya H, Manandar IA. 2020. Strategies for increasing food security in minimizing stunting in Sukabumi District. Agrisep's Journal 19(2): 255-274. https://doi.org/10.31186/agrisep.19.2.255-274.

Supardi S, Erlyna WR, Aulia Q. 2017. Mapping of food insecurity conditions at the regional level in Bojonegoro Regency. Journal of Agricultural Sciences 16 (2): 84-90.

Tambunan, Sincere TH. 2001. Indonesian Economy Theory and Empirical Findings. Jakarta: Ghalia Indonesia. 